\title{
PROTOTIPE MODIFIKASI ERGOCYCLE DENGAN MEMANFAATKAN SEPEDA BEKAS SEBAGAI SOLUSI PEMENUHAN KEBUTUHAN AKTIVITAS AEROBIC TUNANETRA
}

\author{
${ }^{1}$ Onyas Widianingsih
}

${ }^{2}$ Zuraidah

\author{
Correspondence: Universitas Negeri Medan, Medan, Indonesia \\ E-mail: onyaswidia@gmail.com, zuraidah@gmail.com
}

\begin{abstract}
Abstrak
Penelitian ini bertujuan untuk memenuhi kebutuhan aktivitas aerobik tunanetra melalui pengembangan alat bagi siswa SLB- A kelas V, VI, VII dan VIII Karya Murni Medan Johor. Penelitian ini menghasilkan produk pengembangan berupa prototipe modifikasi ergocycle dengan memanfaatkan sepeda bekas disesuaikan dengan kaidah yang sesungguhnya menurut para ahli, karakterstik kebutuhan tunanetra, ketersediaan sarana serta dana oleh pihak yayasan Sekolah Luar Biasa (SLB - A) Karya Murni Medan Johor juga ditinjau dari cukupnya ketersedian bahan baku pembuatan alat. Metode penelitian ini adalah penelitian dan pengembangan dengan tahapan penelitian sebagai berikut: (1) potensi dan masalah, (2) pengumpulan data, (3) desain produk, (4) validitas desain, (5) revisi desain, (6) uji coba skala kecil, (7) revisi produk, (8) uji coba skala besar, (9) revisi (penyempurnaan), (10) hasil akhir prototipe modifikasi ergocycle dengan memanfaatkan sepeda bekas sebagai solusi pemenuhan kebutuhan aktivitas aerobik tunanetra. Hasil penelitian dan pembahasan mengenai kepuasan konsumen yang tertuang dalam empat aspek yaitu; 1) keamanan, 2) kenyamanan, 3) estetika dan, 4) tampilan. Keempat aspek tersebut telah disesuaikan dengan karakteristik tunanetra sebagai konsumen pengguna alat, dan merupakan hasil dari diskusi pada ahli penjas adaptif dan ahli otomotif. Setelah dilakukan uji coba produk, maka diperoleh tingkat kepuasan sebesar 55,92\% dari hasil uji coba skala kecil, dan diperoleh tingkat kepuasan sebesar 92,5\% dari hasil uji coba skala besar. Disimpulkan bahwa pengembangan prototipe modifikasi ergocycle dengan memanfaatkan sepeda bekas ini mengalami peningkatan yang signifikan dan dapat digunakan untuk memenuhi kebutuhan aktivitas aerobik siswa SLB - A Karya Murni Medan Johor.
\end{abstract}

\section{Kata Kunci: Ergocycle, Modifikasi, Prototipe, Sepeda Bekas}

\section{Pendahuluan}

Manusia sangat memerlukan kebugaran. Selaras pula dengan Deklarasi Universal Hak Asasi Manusia yang ditetapkan oleh Majelis Umum Perserikatan Bangsa-Bangsa dalam Resolusi 217 A (III) tanggal 10 Desembar 1948 dalam Pasal 1 menyatakan "semua manusia lahir bebas dan setara dalam martabat dan hak-haknya Mereka dikaruniai akal pikiran, hati nurani dan hakekatnya memperlakukan sesamanya dengan semangat persaudaraan", BAB III Pasal 4: "setiap orang berhak atas kesehatan", kemudian diperkuat kembali oleh Pasal 12 Ayat 1: "mengakui hak setiap orang untuk menikmati standar yang dapat dicapai atas kesehatan fisik dan mental". Dengan alasan diatas, maka jelas bahwa seorang tunanetra juga sangatlah membutuhkan kebugaran dan kesehatan secara utuh baik fisik, mental, spiritual maupun sosial sehingga memungkinkan seseorang tersebut untuk hidup produktif secara sosial dan ekonomis. 
Pada era yang kompleks ini kesadaran masyarakat akan pentingnya kesehatan sangatlah tinggi, maka tak jarang masyarakat menyisihkan waktu dan materil untuk memenuhinya. Pada umumnya masyarakat memanfaatkan waktu libur untuk mengunjungi pusat-pusat kebugaran baik yang dapat diperoleh secara gratis maupun harus mengeluarkan biaya seperti; turut serta pada senam pagi hari minggu dilapangan merdeka Medan, mengunjungi pusat-pusat kebugaran fitness, kolam renang UNIMED, senam aerobik yang dikelolah oleh dosen-dosen dan mahasiswa FIK-UNIMED rutin tiga kali seminggu didepan stadion UNIMED, atau hanya sekedar jogging dilapangan serba guna UNIMED dan selain itu masih banyak tempat-tempat lain atau pusat-pusat pelayanan kebugaran lain yang sering dikunjungi oleh masyarakat.

Aktivitas diatas merupakan bentuk sadar manusia dalam mewujudkan kesehatan, karena kesehatan merupakan modal penting bagi setiap manusia untuk mempertahankan dan memperbaiki kualitas hidupnya. Aktivitas tersebut diatas sangat membantu sistem aerobik tubuh seseorang sehingga seseorang tersebut dapat memperoleh kesehatan serta kebugaran seperti yang diharapkan. Bagi seorang penyandang tunanetra, maka aktivitas diatas akan terasa sulit dilakukan karena keterbatasan yang mereka miliki yaitu tidak dapat melihat suatu objek dengan jelas sama seperti orang awas pada umumnya.

Berdasarkan hasil survei yang peneliti lakukan di Sekolah Luar Biasa (SLB - A) Karya Murni Medan Johor, informasi yang diperoleh diantaranya yaitu; ketersediaan sarana dan prasarana disekolah sangat terbatas, minat siswa dalam bermain dan berolahraga dengan menggunakan alat cukup tinggi terbukti ketika jam pelajaran pendidikan jasmani anak-anak banyak yang berebut menggunakan alat. Waktu yang digunakan untuk beraktivitas sedikit karena mata pelajaran pendidikan jasmani berlaku pada jam yang sama untuk semua kelas, yaitu Mulai kelas 1 SD - IX SMP. Ketersediaan sarana tidak memadai untuk menampung keseluruhan jumlah siswa dan hanya dapat dipakai secara bergantian. Pihak yayasan belum mampu menambah unit sarana tersebut karena harga terbilang mahal seperti contoh satu set permainan goal ball yaitu berkisar harga Rp.6.500.000 sampai Rp.8.000.000. Goal ball merupakan permainan baru yang dirancang khusus untuk seorang tunanetra dengan tiga orang maksimal pemain. Saat ini sekoah SLB - A Karya Murni hanya memiliki satu set, karena keterbatasan dana. Alat tersebut hanya diproduksi diluar Negeri. Keberadaan Goal ball masih terbatas terbukti di kota Medan hanya ada dua unit tersedia yaitu di National Paralympic Comitte (NPC) dan yayasan SLB - A Karya Murni Medan Johor.

Berdasarkan penjelasan diatas peneliti menyimpulkan bahwa ada beberapa permasalahan yang dihadapi pihak sekolah dan manjadi perhatian peneliti yaitu; siswa memiliki sedikit peluang untuk melakukan aktivitas yang bersifat aerobik disamping itu pula karena mata pelajaran pendidikan jasmani keseluruhan kelas berlangsung pada jam yang sama, dana yang tersedia dari pihak yayasan tidak cukup untuk menambah unit sarana yang dibutuhkan berhubung harga alat yang selama ini tersedia dipasaran cukup mahal.

Dalam hal ini peneliti menawarkan solusi dengan menciptakan produk nyata. Sehingga diharapkan dapat membantu memenuhi kebutuhan aktivitas 
aerobic tunanetra. Produk ini dirancang sesuai kebutuhan yang diperlukan, instrumen atau alat yang dapat digunakan untuk memenuhi kebutuhan tersebut berupa prototipe modifikasi ergocycle dengan memanfaatkan sepeda bekas. Penelitian ini akan mengkaji dalam pengembangan prototipe modifikasi ergocycle dengan memanfaatkan sepeda bekas untuk memenuhi kebutuhan aktivitas aerobik tunanetra. Secara teknis cara pelaksanaan beserta perlengkapan yang di butuhkan cenderung sama dengan alat yang selama ini digunakan, tetapi disini permasalahannya adalah alat tersebut yang selama ini telah banyak digunakan, cenderung mahal dan masih sulit diperoleh, pada prototipe modifikasi ergocycle dengan memanfaatkan sepeda bekas sebagai solusi pemenuhan kebutuhan aktivitas aerobik tunanetra menjanjikan nuansa yang berbeda dimana alat ini bernilai ekonomis, efektif dan efisien.

Alat tersebut sangat di dambakan oleh seorang tunanetra untuk dapat mengembangkan kemampuan aerobik tubuhnya. Tidak menutup kemungkinan pula alat ini juga dapat digunakan oleh seorang yang normal. Sehingga dalam hal ini, yakni KONI pusat maupun daerah, Fakultas Ilmu Keolahragaan dan pusatpusat olahraga di seluruh Indonesia, dapat mengembangkannya karena alat tersebut sangat dibutuhkan. Dengan demikian adanya alat tersebut di harapkan proses pemenuhan kebutuhan aerobik bagi tunanetra dapat lebih mantap dan dapat menjawab permasalahan yang terkini dengan sarana yang mendukung.

Sebagai bentuk pengembangan atau modifikasi dari alat yang telah ada tersebut di atas, maka dianggap perlunya untuk membuat pengembangan alat prototipe modifikasi ergocycle dengan memanfaatkan sepeda bekas sebagai solusi pemenuhan kebutuhan aktivitas aerobic tunanetra. Dampak lain akan memberi peluang pada pihak industri dalam negeri berinovasi mendesain prototipe alat lain untuk memenuhi dan mengembangkan komponen daya tahan tubuh secara aerobik, juga menjalin kerja sama dengan perguruan tinggi dalam mengembangkan industri olahraga untuk memenuhi kebutuhan pasar. Menghasilkan produk nyata memanfaatkan barang bekas dengan luaran sepeda statis yang bernilai ekonomis, efektif dan efisien untuk dapat dimanfaatkan oleh tunanetra khususnya dan kalangan normal pada umumnya.

Ergocycle adalah alat yang dirancang menyerupai bentuk sepeda dan memiliki beban atau tingkat kesukaran sesuai kebutuhan sipemakai. Terbuat dari besi, alumunium dan juga pelastik.

Sepeda adalah sebuah kendaraan ringan memiliki dua roda satu di belakang yang lain. Ini memiliki kursi pelana dan didorong oleh kaki pengendara bertindak atas engkol atau tuas.

Aktivitas merupakan suatu kegiatan atau keaktifan. Jadi segala sesuatu yang dilakukan atau kegiatan-kegiatan yang terjadi baik fisik maupun non-fisik, merupakan suatu aktivitas. (L. K., Marlina Lubis, 2011).

Menurut Kamus Besar Bahasa Indonesia ae.ro.bik/aérobik/ a bersifat memerlukan oksigen bagi kehidupan, gerak dan pertumbuhannya (Alwi, Hasan, 2007).

Sardegna, 2002; dalam Harimukthi, M., T dan D. K., Sari (2014), menjelaskan bahwa tunanetra adalah individu yang kehilangan penglihatan karena kedua indera penglihatannya tidak berfungsi seperti orang awas. 
Kotler (1997) dalam H.S., Agyl (2012), kepuasan konsumen adalah perasaaan senang atau kecewa seseorang yang berasal dari perbandingan antara kesannya terhadap kinerja (hasil) sesuatu produk dengan harapannya.

\section{Metode}

Penelitian pengembangan ini menggolongkan subyek ujicoba menjadi dua, yaitu subyek untuk ujicoba ahli materi dan media. Subyek uji coba media yaitu; siswa SLB - A Karya Murni Medan Johor kelas V, VI, VII dan VIII dengan Uji coba skala kecil (5 orang) kalas VII dan VIII dan uji coba skala besar (10 orang). Instrumen untuk mengumpulkan data dalam pengembangan ini adalah dengan menggunakan angket (kuesioner). Angket atau kuesioner merupakan teknik pengumpulan data yang dilakukan dengan cara memberi seperangkat pertanyaan atau pernyataan tertulis kepada responden untuk dijawabnya Sugiyono, (2016). Pengumpulan data peneliti ini menggunakan angket tertutup.

Setelah data terkumpul, maka data tersebut diklasifikasikan menjadi dua kelompok data, yaitu data kualitatif dan data kuantitatif. Data yang bersifat kualitatif diperoleh melalui kegiatan validasi ahli dan kegiatan ujicoba yang berupa masukan, tanggapan serta kritik dan saran. Data yang bersifat kuantitatif yang berupa penilaian, dihimpun melalui angket atau kuesioner ujicoba produk pada saat kegiatan ujicoba di SLB - A Karya Murni Medan Johor, dianalisis dengan analisis statistik deskriptif, yang berupa pernyataan SANGAT BAIK, BAIK dan CUKUP BAIK yang diubah menjadi data kuantitatif dengan skala penskoran 1 sampai 10. Selanjutnya hasil dari uji coba produk tersebut dipersentase. Dikatakan layak apabila hasil menunjukkan persentase diatas $70 \%$.

\section{Pembahasan}

Tabel 1. Data Hasil Uji Coba Skala Kecil (N=5)

\begin{tabular}{clc} 
No & \multicolumn{1}{c}{ Pertanyaan } & Prolehan Nilai \\
\hline $\mathbf{1}$ & $\begin{array}{l}\text { Bagaimana menurut anda jika ada penambahan sarana untuk } \\
\text { beraktivitas? }\end{array}$ & 10 \\
$\mathbf{2}$ & Apa anda suka dengan sepeda ini? & 11 \\
$\mathbf{3}$ & Bagaimana menurut anda cara penggunaan sepeda ini? & 12 \\
$\mathbf{4}$ & Apa yang anda rasakan ketika menggunakan sepeda ini? & 11 \\
$\mathbf{5}$ & Bagaimana dengan stangnya? & 7 \\
$\mathbf{6}$ & Bagaimana dengan sadelnya? & 8 \\
$\mathbf{7}$ & Bagaimana dengan pedalnya? & 10 \\
$\mathbf{8}$ & Apa ada yang perlu ditambah? & 5 \\
$\mathbf{9}$ & Apa ada yang perlu dikurang? & 5 \\
$\mathbf{1 0}$ & Jika alat ini tersedia disekolah apan anda akan menggunakannya? & 10
\end{tabular}


Tabel 2. Data Hasil Uji Coba Skala Besar $(\mathrm{N}=10)$

\begin{tabular}{clc} 
No & \multicolumn{1}{c}{ Pertanyaan } & Skor Jawaban \\
\hline $\mathbf{1}$ & Menurut anda apakah cara menggunakan sepeda ini sulit? & 82 \\
$\mathbf{2}$ & $\begin{array}{l}\text { Apa yang anda rasakan dengan stangnya ketika menggunakan } \\
\text { sepeda ini? }\end{array}$ & 79 \\
$\mathbf{3}$ & $\begin{array}{l}\text { Apa yang anda rasakan dengan sadelnya ketika menggunakan } \\
\text { sepeda ini? }\end{array}$ & 91 \\
$\mathbf{4}$ & Apa yang anda rasakan dengan pedalnya ketika menggunakan & 83 \\
$\mathbf{5}$ & sepeda ini? & 82 \\
$\mathbf{6}$ & $\begin{array}{l}\text { Apa anda suka degan sepeda ini? } \\
\mathbf{7}\end{array}$ & Apa ada yang perlu ditambakan? \\
$\mathbf{8}$ & Jika alat ini tersedia dikurang? & 100 \\
&
\end{tabular}

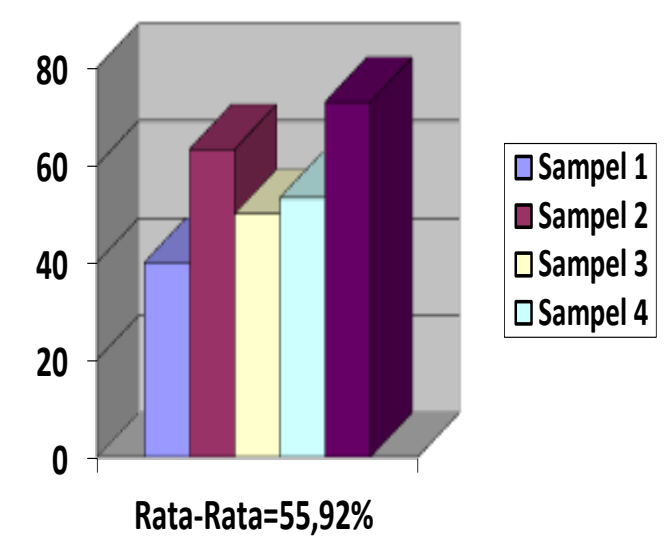

Gambar 1. Grafik Persentase Kuisioner Sampel Tunanetra Skala Kecil 


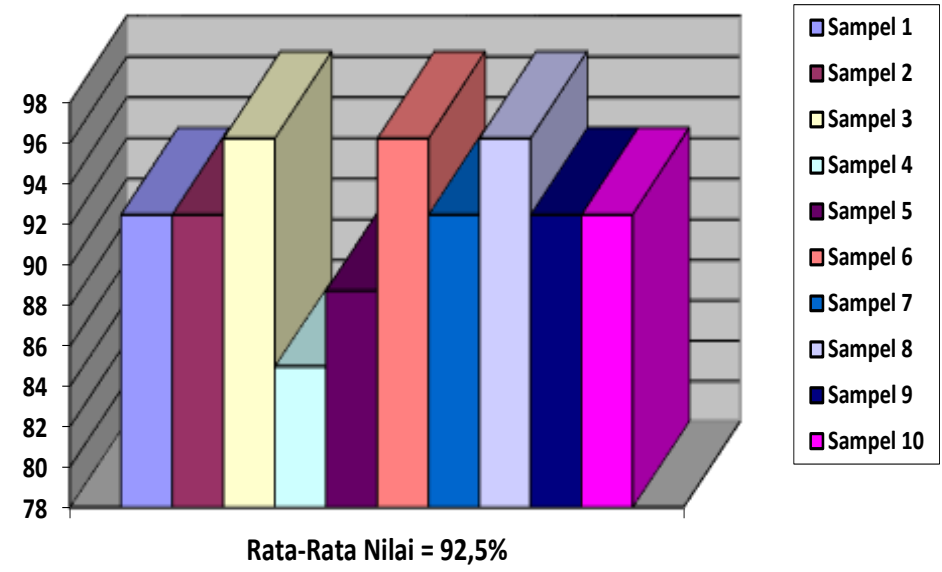

Gambar 2. Grafik Persentase Kuisioner Sampel Tunanetra Skala Besar

\section{Prototipe Produk}

Hasil akhir dari kegiatan Penelitian pengembangan ini adalah produk prototipe modifikasi ergocycle dengan memanfaatkan sepeda bekasberdasarkan data pada saat uji coba skala kecil $(\mathrm{N}=5)$ dan uji coba skala besar $(\mathrm{N}=10)$.

Hasil diskusi dengan kedua para pakar ahli penjas adaptif dan ahli otomotif sesuai dengan keempat kriteria yaitu tingkat; 1. kenyaman, 2. keamanan, 3. estetika dan 4. tampilan produk, maka menyatakan bahwa prototipe modifikasi ergocycle dengan memanfaatkan sepeda bekas layak dan sangat baik untuk dikambangkan dalam memenuhi aktivitas aerobik tunanetra.

Hasil analisis data uji coba skala kecil sesuai dengan keempat aspek yang dinilai yaitu; 1) keamanan, 2) kenyamanan, 3) estetika dan, 4) tampilan memperoleh tingkat kepuasan sebesar 55,92\%. Berdasarkan kriteria yang telah ditentukan maka model prototipe modifikasi ergocycle dengan memanfaatkan sepeda bekas termasuk dalam kategori baik, sehingga dari uji coba skala kecil model ini layak digunakan untuk siswa kelas VII dan VIII Sekolah SLB - A Karya Murni Medan Johor.

Faktor yang menjadikan prototipe ini dapat diterima siswa kelas VII dan VIII Sekolah SLB - A Karya Murni Medan Johor adalah dari semua aspek yang diuji coba, 90\% siswa menyukai prototipe yang dicoba. Secara keseluruhan baik dari uji coba skala kecil mapun uji coba skala besar menunjukkan bahwa prototipe modifikasi ergocycle dengan memanfaatkan sepeda bekas ini dapat diterima siswa tunanetra dengan baik, sehingga model ini dapat digunakan untuk siswa kelas V, VI, VII dan VIII Sekolah SLB - A Karya Murni Medan Johor.

Hasil analisis data uji coba skala besar sesuai dengan keempat aspek yang dinilai yaitu; 1) keamanan, 2) kenyamanan, 3) estetika dan, 4) tampilan memperoleh tingkat kepuasan konsumen sebesar 92,5\%. Berdasarkan kriteria yang telah ditentukan maka prototipe modifikasi ergocycle dengan memanfaatkan sepeda bekas ini telah memenuhi kriteria sangat baik, sehingga dari uji coba 
kelompok besar model ini sangat layak digunakan untuk siswa tunanetra kelas V, VI, VII dan VIII Sekolah SLB - A Karya Murni Medan Johor.

Produk prototipe modifikasi ergocycle dengan memanfaatkan sepeda bekas" ini sudah dapat digunakan untuk dapat meningkatkan aktivitas aerobik tunanetra. Hal ini dikarenakan dari keberhasilan modifikasi ergocycle dengan memanfaatkan sepeda bekas yang dapat diterima siswa SLB - A Karya Murni Medan Johor serta meningkatnya prosentase kepuasan konsumen dari uji coba skala kecil menuju uji coba skala besar dari 55,92\% meningkat menjadi 92,5\%.

Faktor yang menjadikan model permainan dapat diterima siswa Sekolah Dasar yaitu: Faktor yang menjadikan model permainan dapat diterima siswa tunanetra yaitu dengan memodifikasi alat seperti; (1) Menambahkan sepeda dengn rem tangan bekas, (2) Menggunakan pengaman (penutup) kedua pelak ban dengan bahan seng dan pipa bekas, (3) Menggunakan pengaman pada rantai menggunakan seng dan selang lunak bekas, (4) Membalut semua bagian besi yang membentuk siku terutama pada bagian penyangga dengan koran, karpet bekas dan lakban hitam, (5) Mengganti stang lama berbentuk melengkung dengan stang yang lurus dan lebih tinggi, (6) Mengganti sadel dengan bahan yang lembut terbuat dari bahan busa, (7) Menambahkan pedal dengan sabuk yaitu memanfaatkan sendal bekas, (8) Menambah panjang besi kayuhan pedal yaitu menyambungnya dengan menambahkan besi lain yang berukuran sama dengan cara mengelasnya, (9) Mengecat sepeda dengan menggunakan pylox warna merah dan silver.

Menerapkan modifikasi pada ergocycle dengan dengan memanfaatkan sepeda bekas juga alat penunjang lain seperti; pelak ban, tali sabuk timba sumur dan katrrol yang keseluruhan alat berasal dari barang bekas kemudian didesain, dirakit, dikemas lalu diproduksi dalam bentuk yang sederhana.

Hasil produksi dalam bentuk sederhana tersebut tetap dapat digunakan dalam meningkatkan aktivitas aerobik tunanetra, karena aktivitas aerobik penting dilakukan berguna untuk menjaga kesehatan serta kebugaran tubuh agar siswa tunanetra dapat hidup secara produktif secara sosial dan ekonomi diantaranya yang terpenting yaitu melaksanakan aktivitas yang lebih terutama dalam mengikuti proses pembelajaran disekolah sesuai dengan tuntutan kurikulum yang telah ditetapkan dengan menggunakan sarana (sepeda) yang telah dimodifikasi tanpa mengurangi nilai-nilai ergocycle yang terkandung didalamnya.

Terciptanya produk tersebut sanagat disambut baik oleh siswa, guru pendidikan jasmani dan pihak sekolah, karena dengan terciptanya produk tersebut, maka dapat meringankan beban pihak yayasan dari segi penambahan unit sarana disekolah berkaitan dengan keterbatasan dana tentu pula membuka peluang bagi siswa untuk menggunakan produk tersebut pada jam pelajaran penjas dan memanfaatkannya untuk melakukan aktivitas yang lebih lama dari biasa.

Aktivitas aerobic dapat terpenuhi melalui pengembangan produk prototipe modifikasi ergocycle dengan memanfaatkan sepeda bekas sebagai solusi pemenuhan kebutuhan aerobik tunanetra dikaji berdasarkan karakteristik bahan yang menjadi contoh (prototipe) yaitu ergocycle dan bahan dasar pembuatan produk tersebut yaitu sepeda. 
Ergocycle dan sepeda keduanya memiliki ciri yang sama yaitu samasama alat yang dapat dipakai untuk pemanasan sistem kardio respirasi (sistem aerobik tubuh). selain dari karakteristik prototipe dan bahan dasar pembuatan produk yang digunakan untuk mengelolah sistem aerobik tubuh, maka disamping itu pula guru pendidikan jasmani disekolah bertanggung jawab atas terpenuhinya kebutuhan aktivitas aerobic siswa terkhusus pada jam pelajaran pendidikan jasmani berlangsung peran guru yaitu memberi kesempatan pada siswa untuk menggunakan produk dengan rentang waktu 5 sampai 10 menit setiap siswa dilakukan secara bergantian, sehingga dengan demikian aktivitas aerobik dapat terpenuhi dan produk benar-benar bermanfaat memenuhi kebutuhan aerobik.

\section{Kajian Produk}

Hasil akhir dari kegiatan penelitian pengembangan ini adalah produk "prototipe modifikasi ergocycle dengan memanfaatkan sepeda bekas sebagai solusi pemenuhan kebutuhan aktivitas aerobic tunanetra" yang telah di sesuaikan dengan keempat kriteria dari hasil diskusi pada para ahli yaitu tingkat; 1. kenyaman, 2. keamanan, 3. estetika dan 4. tampilan produk, yang berdasarkan data pada saat uji coba skala kecil dan uji coba skala besar kemudian juga keafektifannya dalam memenuhi aktifitas aerobik siswa.

\section{Simpulan}

Berdasarkan hasil penelitian dan pembahasan dalam skripsi ini, maka dapat disimpulkan sebagai berikut:

1) Produk prototipe modifikasi ergocycle dengan memanfaatkan sepeda bekas dapat dan layak digunakan dan dipraktikan kepada subjek uji coba. Hal itu berdasarkan analisis data pada uji coba skala kecil diperoleh rata-rata persentase $55,92 \%$. Berdasarkan kriteria yang telah ditetapkan maka produk prototipe modifikasi ergocycle dengan memanfaatkan sepeda bekas ini telah memenuhi kriteria baik dan layak digunakan.

2) Produk prototipe modifikasi ergocycle dengan memanfaatkan sepeda bekas sudah dapat digunakan untuk dapat meningkatkan aktivitas aerobik tunanetra. Hal itu berdasarkan analisis data uji coba skala kecil didapat rata-rata persentase pilihan jawaban 55,92\% dengan kriteria baik dan hasil analisis data uji coba skala besar didapat rata-rata persentase pilihan jawaban 92,5\% dengan kriteria sangat baik. Berdasarkan kriteria yang telah ditentukan maka prototipe modifikasi ergocycle dengan memanfaatkan bekas dapat digunakan sebagai solusi pemenuhan kebutuhan aktivitas aerobic tunanetra.

3) Faktor yang menjadikan prototipe ini dapat diterima siswa SLB - A adalah dari semua aspek yang diuji coba, $90 \%$ siswa menyukai semua aspek yang dinilai berdasarkan keempat kriteria; yaitu tingkat; 1. kenyaman, 2. keamanan, 3. estetika dan 4. tampilan produk, prototipe yang dicoba. Secara keseluruhan prototipe modifikasi ergocycle dengan memanfaatkan sepeda bekas ini dapat diterima siswa tunanetra dengan baik, sehingga uji coba skala kecil model ini dapat digunakan untuk siswa kelas V, VI, VII dan VIII Sekolah SLB - A Karya Murni Medan Johor. 


\section{Rujukan}

Abdoellah, Arma, 1996. Pendidikan Jasmani Adaptif. Jakarta: Penerbit Direktur Jendral Pendidikan Tinggi

Alwi, Hasan, 2007. Kamus Besar Bahasa Indonesia. Cetakan ke empat. Jakarta: Balai Pustaka

Brick, Lynne, 2001. Bugar dengan Senam Aerobik. Cetakan ke satu. Jakarta: Penerbit PT Raja Grafindo Persada

Corwin, Elizabeth J, 2009. Patofisiologi. Cetakan ke tiga. Jakarta: Penerbit Kedokteran EGC

Defenisi Sepeda. Diakses 29 Agustus 2016 dari

http://translate.google.co.id/translate?hl=id\&langpair =en|id\&u=http://www. brainyquote.com/words/bi/bicycle136632.html.13:06//.

Haryati, Sri, 2012. Research and Development (R\&D) Sebagai Salah Satu Model Penelitian Dalam Bidang Pendidikan. Jurnal FKIP-UTM. 37 (1): 11-26

Hakim, W.L. (2016). Pengertian Prototype. Diakses pada 29 Agustus 2016 dari http://www.scribd.com/doc/58298607/.

H. S., Agyl, 2012. Pengaruh Kualitas Produk Dan Tingkat Kepuasan

KonsumenTerhadap Loyalitas Pelanggan Pada Produk MakananTela Krezz Cabang Bekasi.Artikel Ilmiah Universitas Guna Darma

Isakayoga, G. (2011). Memahami HAM dengan Lebih Baik. Jakarta: Penerbit PT Raja Grafindo Persada.

L. K., Marlina, 2011. Peningkatan Aktivitas Pembelajaran Hidrosfer Dan Dampaknya Terhadap Kehidupan Melalui Tindakan Guru Inovatif Pada Kelas X Di Sma Negeri 1 Semarang.Jurnal Geografi, 8 (1): 21-31

M, Muchammad, 2007. "Pengaruh Latihan Aerobik Terhadap Perubahan Vo2 Max Pada Siswa Sekolah Sepak Bola Tugu Muda Semarang Usia 12-14 Tahun. Semarang, FK Universitas Diponegoro Semarang

Manfaat Bersepeda. diakses 29 Agustus 2016 dari http://lawan.us/lifestyle/bersepeda-untuk-menjaga-alam-dankesehatan/.13/06/2011.13:43//

Nadiyah. Abdullah, 2012. Bagaimana Mengajar Anak Tunanetra (Di Sekolah Inklusi). Jurnal Staf Pengajar Prodi Psikologi Fakultas Psikologi UNWIDHA Klaten, 28 (10): 12-26

S.M., Theresia, 2012. Pelaksanaan Kembelajaran Keterampilan Penggunaan Tongkat bagi Anak Tunanetra. Jurnal Ilmiah Pendidikan Khusus, 1 (2): 46-58

Sugiyono, 2016. Metode Penelitian Kualitatif, Kuantitatif dan R\&D. Cetakan ke dua puluh tiga. Bandung: Penerbit Alfabeta

PJKR_

http://jurnal.unimed.ac.id/2012/index.php/jpehr/index 